\title{
Implementasi Sistem Pendukung Keputusan Penerima Bantuan Rumah Tidak Layak Huni Berbasis Web
}

\author{
Tri Sugihartono ${ }^{[1]}$, Dian Ardiansyah ${ }^{[2]}$, Muhammad Zakky ${ }^{[3]}$ \\ Jurusan Teknik Informatika, STMIK Atma Luhur Pangkalpinang \\ trisugihartono@atmaluhur.ac.id ${ }^{[1]}, \underline{1411500184 @ \text { mahasiswa.atmaluhur.ac.id }}{ }^{[2]}, 1411500195 @$ atmaluhur.ac.id ${ }^{[3]}$
}

\begin{abstract}
Saat ini teknologi informasi berkembang sangat pesat, hal tersebut memberikan dampak bagi suatu organisasi, baik dibidang instansi pemerintah, swasta, pendidikan, wirausahawan, dan para pelaku bisnis yang bergerak di sektor sektor bisnis lainnya. Dinas Perumahan Rakyat dan Kawasan Permukiman merupakan instansi pemerintah serta sistem penentuan penerima bantuan rumah tidak layak huni masih bersifat subjectif sehingga mengakibatkan masalah pada proses pemeriksaan oleh Inspektorat, ditemukan rumah - rumha yang seharusnya tidak berhak mendapatkan bantuan diperbantukan dan manajemen pendataan masih dilakukan manual sehingga saat pimpinan daerah meminta data kepada instansi ini membutuhkan waktu yang lama sehingga dianggap tidak efisien dan efektif. Dengan alasan diatas penulis mencoba untuk memberikan solusi dengan membuat suatu sistem informasi pendukung keputusan penerima rumah tidak layak huni serta akan dibuat secara sistematis dan lebih terkomputerisasi. Pada penulisan penelitian ini juga di dokumentasikan tahapan pengerjaannya seperti proses anaisa, perancangan, coding hingga testing menggunakan Unified Modelling Language (UML), Activity Diagram, Sequence Diagram kemudian menggunakan bahasa pemrograman Hypertext Preprocessor (PHP) dengan kerangka kerja CodeIgniter dan Databse MySQL, dengan tujuan untuk mengetahui sistem yang berjalan dan kebutuhan sistem yang akan dikembangkan. Dengan adanya sistem yang lebih terkomputerisasi dapat menghasilkan informasi alternatig keputusan pemillihan penerima bantuan rumah tidak layak huni sekaligus pengolahan manajemen data tersusun dengan rapi.
\end{abstract}

Kata Kunci-Sistem Pendukung Keputusant; CodeIgniter; PHP ; MySql; Rumah Layak Huni

\section{PENDAhUluan}

Saat ini teknologi informasi berkembang sangat pesat, hal tersebut memberikan dampak bagi suatu organisasi. Baik dibidan ginstansi pemerintah, swasta, pendidikan, wirausahawan, dan para pelaku bisnis yang bergerak di sektor sektor bisnis lainnyua. Pemanfaatan peran teknologi informasi sebagai alat untuk menunjang proses bisnis agar dapat memberikan keuntungan dan kemudahan dalam operasional proses bisnis, sehingga dapat memberikan layanan yang baik, respons yang cepat dan tindakan yang tepat menjadi aset penting dalam suatu bisnis dan menuntut pihak pengelola organisasi berupaya untuk membangun, membuat, merancang, sekaligus memanfaatkan teknologi, serta sistem informasi dengan tujuan dapat membantu mempermudah dan menyederhanakan proses proses bisnis yang sebelumnya dinilai kurang efisien menjadi lebih efektif.

Rumah tidak layak huni adalah rumah yang tidak memenuhi persyaratan keselamatan bangunan dan kecukupan minimal dalam unsur ruang dan luas ruangan. Selain itu, juga memperhatikan kualitas material pembangunan seperti dinding, hingga memenuhi aspek pendidikan bagi siapa pun menempatinya.

Dinas perumahan rakyat kawasan permukiman provinsi kepulauan bangka belitung membuat program rumah tidak layak huni bertujuan untuk meningkatkan rumah yang tidak layak huni menjadi layak huni, dalam proses penentuan bantuan kepada penerima bantuan masih bersifat subjektif sehingga mengakibatkan masalah pada saat pemeriksaan oleh Inspektorat, ditemukan rumah - rumah yang seharusnya tidak berhak mendapatkan bantuan diperbantukan dan manejemen pendataan masih dilakukan manuas sehingga saat pimpinan daerah meminta data kepada dinas ini membutuhkan waktu yang lama sehingga dianggap tidak efisien dan efektif.

Berdasarkan latar belakang tersebut dinas perumahan rakyat dan kawasan permukiman provinsi kepulauan bangka belitung membutuhkan pemanfaatan secara maksimal sumber daya yang dimiliki berupa sistem informasi dan juga metode penentuan yang bersifat objektif yang nantinya akan memberikan suatu solusi dalam permasalahan mereka selama ini dalam mencari informasi dan bagaimana mendapatkannya serta dapat menentukan penerima bantuan lebih baik dan objektif, sehingga akan meningkatkan kinerja mereka menjadi lebih efieisan dan efektif.

\section{TINJAUAN PUSTAKA}

\section{A. Definisi Sistem}

Sistem adalah hubungan satu unit dengan unit - unit lainnya yang saling berhubungan satu sama lainnya dan yang tidak dapat dipisahkan serta menuju satu kesatuan dalam rangka mencapai tujuan yang telah ditetapkan. Apabila suatu unit macet atau terganggu, unit lainnya pun akan terganggu untuk mencapai tujuan yang telah ditetapkan tersebut [1]. 


\section{B. Sistem Pendukung Keputusan (SPK)}

Sistem pendukung keputusan yang selanjutnya kita singkat dalam penelitian ini menjadi SPK. SPK adalah sebuah sistem yang mampu memberikan kemampuan baik kemampuan pemecahan masalah maupun pengomunikasian untuk masalah semi terstruktur. Secara khusus, SPK adalah sebuah sistem yang mendukung kerja seorang manajer atau sekelompok manajer dalam memecahkan masalah semi terstruktur dengan memberikan informasi atau usulan yang menuju pada keputusan tertentu [2].

Karakteristik sistem pendukung keputusan terdiri dari [2] :

a. Sistem pendukung keputusan dirancang untuk membantu pengambil keputusan dalam memecahkan masalah yang sifatnya semi terstruktur ataupun tidak terstruktur dengan menambahkan kebijaksanaan manusia dan informasi komputerisasi.

b. Dalam proses pengolahannya, sistem pendukung keputusan mengkombinasikan penggunaan model - model analisis dengan teknik pemasukan data konvensional serta fungsi - fungsi pencari / integrasi informasi.

c. Sistem pendukung keputusan, dirancang sedemikian rupa sehingga dapat digunakan / dioperasikan dengan mudah.

d. Sistem pendukung keputusan dirancang dengan menekankan pada aspek fleksibilitas serta kemampuan adaptasi yang tinggi.

\section{Rumah Tidak Layak Huni (RTLH)}

Rumah tidak layak huni adalah rumah yang aspek fisik dan mentalnya tidak memenuhi syarat. Untuk menunjang fungsi rumah sebagai tempat tinggal yang baik maka harus dipenuhi syarat fisik yaitu aman sebagai tempat berlindung, secara mental memnuhi rasa kenyamanan [3].

\section{Dinas Perumahan Rakyat dan Kawasan Permukiman}

Dinas perumahan rakyat dan kawasan permukiman adalah satu kesatuan sistem yang terdiri atas pembinaan, penyelenggaraan perumahan, penyelenggaran kaasan permukiman, pemeliharaan dan perbaikan, pencegah dan peningkatan kualitas terhadap perumahan kumuh, penyediaan tanah, pendanaahn dan sistem permbiayaan, serta peran masyarakat [4].

\section{METODOLOGI}

Metodologi yang digunakan dalam penelitian ini adalah sebagai berikut :

a. Studi Kelayakan

Studi kelayakan yaitu melakukan penelitian dengan jalan wawancara dan obeservasi secara langsung dengan pelaku manajemen Dinas Perumahan Rakyat dan Kawasan Permukiman Provinsi Kepulauan Bangka Belitung mengenai apa permasalahn yang dihadapi oleh Dinas tersebut.

b. Studi Literatur

Mempelajari literatur yang berhubungan dengan konsep dan teori yang relevan dengan materi penelitian serta objek penelitian dilakukan melalui buku, jurnal penelitian, internet dan lainnya.

c. User Requirement
Kami menggunakan metode elisitasi untuk mengumpulkan dan menyeleksi kebutuhan sistem yang diharapkan stakeholder. Elisitasi merupakan rancangan sistem yang diusulkan yang sesuai yang diinginkan atau yang dibutuhkan user. Elisistasi yang dilakukan melalui tiga tahap yaitu elisitasi tahap I, elisitasi tahap II, elisitasi tahap II dan final draft elisitasi.

d. Tahap pembangunan sistem

Tahap pembangunan sistem yang digunakan adalah SDLC.

Model pengembangan yang digunakan pada penelitian ini iala model waterfall. Model waterfall merupakan model pengembangan Sistem Informasi yang sistematik dan berurutan [5]. Alasan penggunaan model waterfall sebagai model pengembangan sistem pendukung keputusan peneriamaan bantuan rumah tidak layak huni berbasis web ialah kebutuhan pihak instansi / dinas telah terdefinisi secara jelas dan tahap tahap pada model waterfall terstruktur secara jelas. Model waterfall (gambar 1) menyediakan pendekatan alur hidup perangkat lunak secara sekuensial atau berurut dimulai dari analisis, desain, pengkodean, dan pengujian.

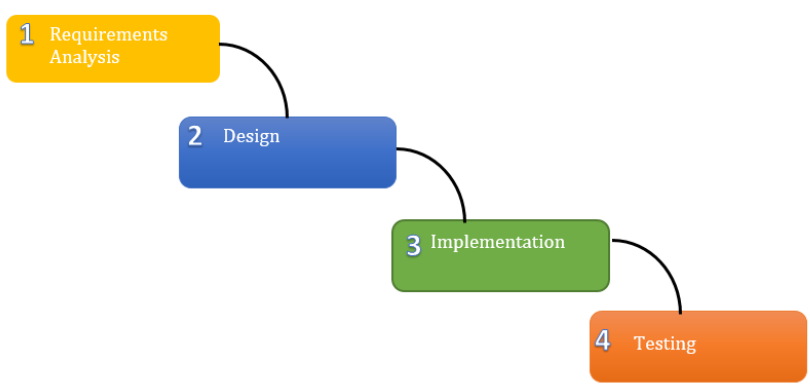

Gambar 1. Model Sistem Waterfall

Pada tahap analisis dilakukan identifikasi masalah pada dengn menggunakan berbagai teknik diantaranya observasi dan wawancara. Pengumpulan data dan informasi yang diperlukan dalam penelitian ini dilakukan dengan melakukan wawancara langsung dengan para pelaku manajemen Dinas Perumahan Rakyat dan Kawasan Permukiman Provinsi Kepulauan Bangka Belitung mengenai apa permasalahan yang dihadapi oleh dinas tersebut.

Pada tahap perancangan (design) dibuat dengan diagram activity, sequence diagram, use case Diagram. selanjutnya membuat rancangan basis data untuk masing masing proses, hubungan aliran data antar proses digambarkan dalam class diagram.

Tahap pengkodean (Implementation) dilakukan dengan menggunakan framework CodeIgniter, dan MySQL sebagai databaenya. Tahap terakhir adalah pengujian (Testing) dengan menggunakan teknik black box testing.

\section{HASIL DAN PEMBAHASAN}

\section{a. Prosedur Sistem Berjalan}

Sistem yang berjalan dalam pendataan calon penerima rumah tidak layak huni pada Dinas Perumahan Rakyat dan Kawasan Permukiman Provinsi Bangka Belitung secara umum yang masih manual. Untuk itu dapat dilihat pada gambar dibawah ini : 


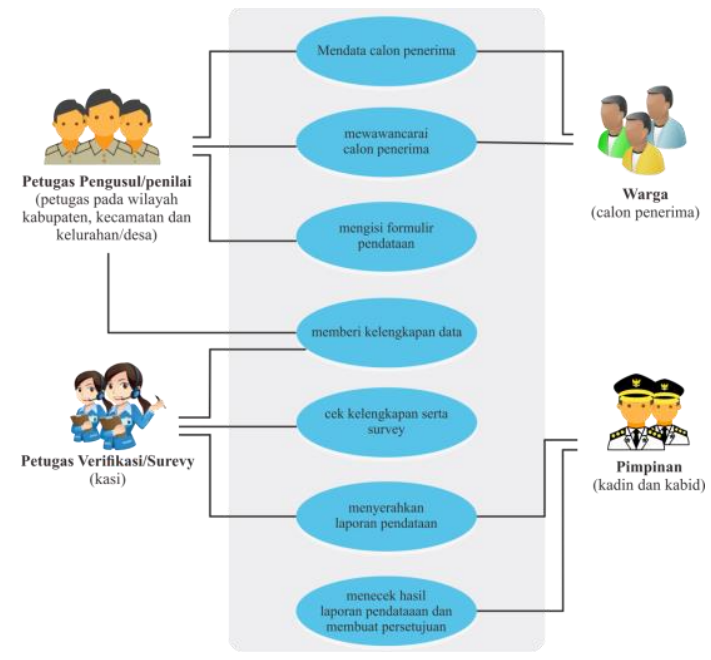

Gambar 2. Use Case Diagram Sistem yang Berjalan

Sistem pendataan calon penerima rumah tidak layak huni pada Dinas Perumahan Rakyat dan Kawasan Permukiman Provinsi Bangka Belitung yang berjalan digambarkan berdasarkan use case diatas, yang memiliki kegiatan sebagai berikut :

1. Satu komponen sistem yang mencakup seluruh kegiatan pendataan calon penerima rumah tidak layak huni

2. Komponen sistem mempunyai 4 aktor yang melakukan kegiatan diantaranya pimpinan, petugas verifikasi / survei, petugas pengusul / penilia dan calon penerima / warga

3. Komponen sistem mempunyai 7 use case yaitu :

a. Mendata calon penerima

b. Mewawancarai calon penerima

c. Mengisi formulir pendataan

d. Memberi kelengkapan data

e. Cek kelengkapan serta survei

f. Menyerahkan laporan pendataan dan

g. Mengecek hasil laporan pendataan dan membuat persetujuan

Dari penjelasan simbol diatas dapat dijelaskan sistem pendataan calon penerima rumah tidak layak huni yang berjalan sebagai berikut :

1. Komponen sistem petugas pengusul / penilai datang ke rumah calon penerima dan mewawancarai calonpenerima

2. Komponen sistem calon penerima rumah tidak layak huni menjawab pertanyaan yang ditanyakan perugas pengusul

3. Komponen sistem petugas pengusul mengisi formulir pendataan sesuai dengan jawaban calon penerima rumah tidak layak huni

4. Komponen sistem petugas pengusul memberikan kelengkapan data kepada petugas verifikasi

5. Komponen sistem petugas verifikasi mengecek kelengkapan data serta mengadakan survei kembali ke calon penerima rumah tidak layak huni

6. Komponen sistem petugas verifikasi menyerahkan pendataan kepada pimpinan Dinas Perumahan Rakyat dan Kawasan Permukiman

7. Komponen sistem pimpinan mengecek hasil laporan pendataan dan membuat persetujuan serta memilih penerima rumah tidak layak huni

\section{b. Rancangan Sistem yang Diusulkan}

Mempelajari dari sistem pendataan calon penerima rumah tidak layak huni di Dinas Perumahan Rakyat dan Kawasan Permukiman yang masih manual, maka dari itu penulis mengusulkan sistem yang lebih terkomputerisasi. Adapun use case diagram yang diusulkan lihat gambar di bawah ini :

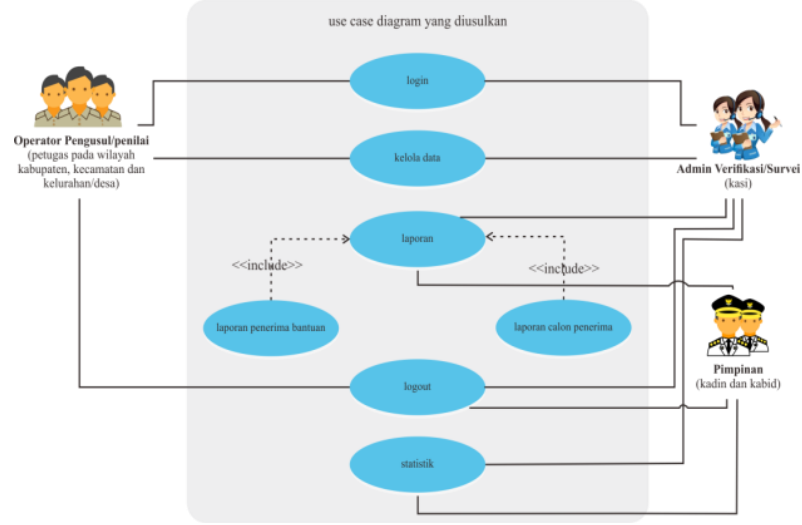

Gambar 3. Use Case Diagram Sistem yang Diusulkan

Berdasarkan gambar diatas Use Case Diagram yang diusulkan terdapat :

1. Komponen sistem mempuyai 1 sistem mencakup seluruh kegiatan sistem pendukung keputusan penerima bantuan rumah tidak layak huni

2. Komponen sistem terdapat 3 aktor yaitu pimpinan, petugas verifikasi / survei sebagai admin dan petugas pengusul / penilai sebagai operator

3. Komponen sistem terdapat 7 use case dilakukan oleh aktor yaitu : login, kelola data, laporan, include laporan penerima bantuan, include laporan calon penerima, logistik dan statistik.

Untuk mendata penerima bantuan rumah tidak layak huni yang efektif maka dati itu penulis mengusulkan sistem yang lebih terkomputerisasi. Adapun activity diagram input penerima bantuan yang diusulkan lihat gambar di bawah ini :

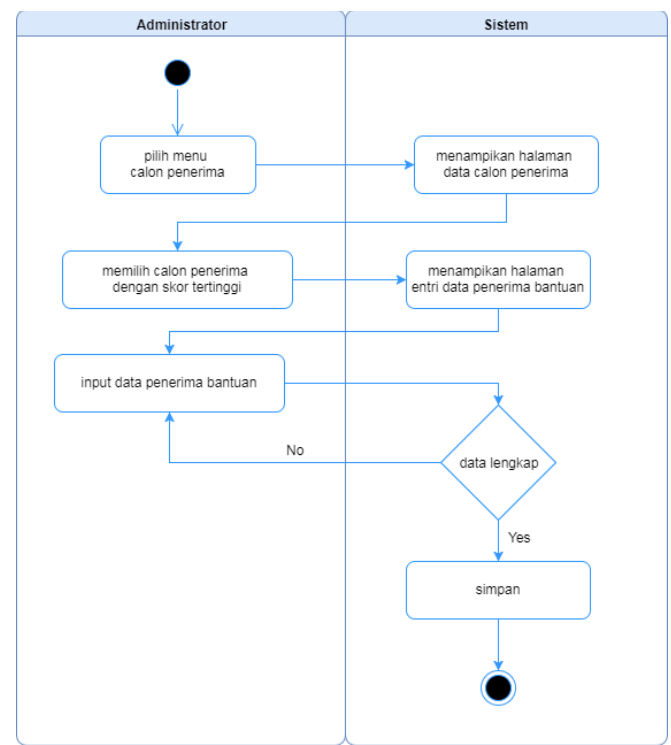

Gambar 4. Activity Diagram Input Penerima Bantuan 
Berdasarkan gambar activity diagram input penerima bantuan yang diusulkan diatas terdapat :

1. Komponen sistem initial node, objek yang diawali.

2. Komponen sistem mempunyai 6 activity yang dilakukan oleh actor

3. Komponen sistem mempunyai 2 vertical swimeline yaitu administrator dan sistem

4. Komponen sistem initial final node yang merupakan aktifitas akhir kegiatan dari sistem

Adapun sistem yang diusulkan oleh penulis mengenai sistem pendukung keputusan penerima bantuan rumah tidak layak huni, bisa dilihat dalam bentuk sequence diagram bagaimana cara kerja sistem usulannya lihat gambar dibawah ini :

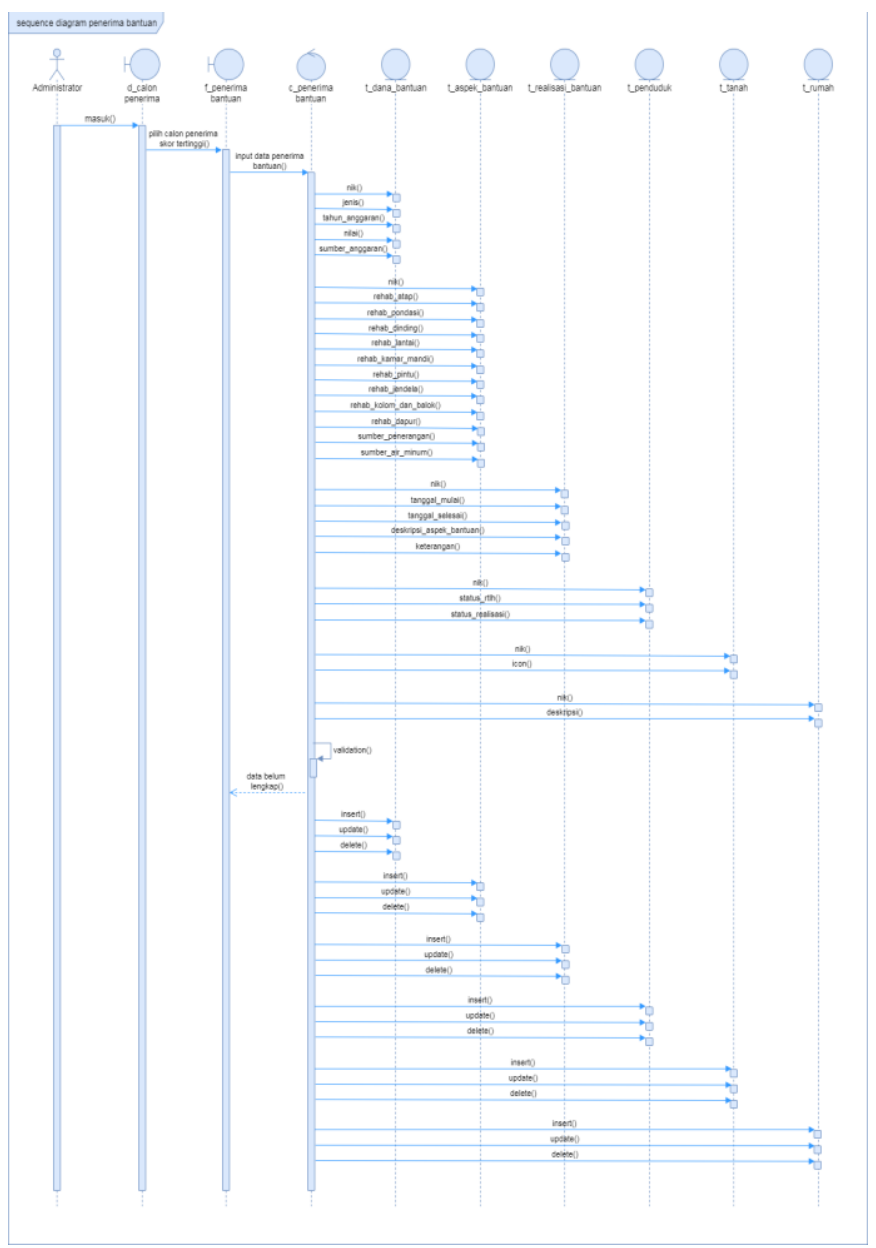

Gambar 5. Sequence Diagram Input Penerima Bantuan

Berdasarkan gambar sequence diagram input penerima bantuan yang diusulkan diatas terdapat:

1. Komponen sistem mempunyai 1 aktor yang melakukan kegiatan yaitu Administrator

2. Komponen sistem mempunyai 1 lifeline yang merupakan objek entity yang saling berkaitan yaitu input penerima bantuan

3. Komponen sistem 54 messages yang memuat informasi informasi yang terjadi, kegiatan yang bisa dilakukan oleh aktor tersebut

\section{c. Rancangan Halaman Pencarian Calon Penerima}

Halaman ini bertujuan untuk mencari calon penerima yang ada pada database penduduk dengan parameter nomor nik dan nama penduduk. Jika data yang dicari ditemukan pada tabel di sebelah kanan akan menampilkan data - data penduduk dan di sebelah kanan akan muncul tombol untuk melanjutkan proses pengisian data calon penerima. Lihat gambar di bawah ini :

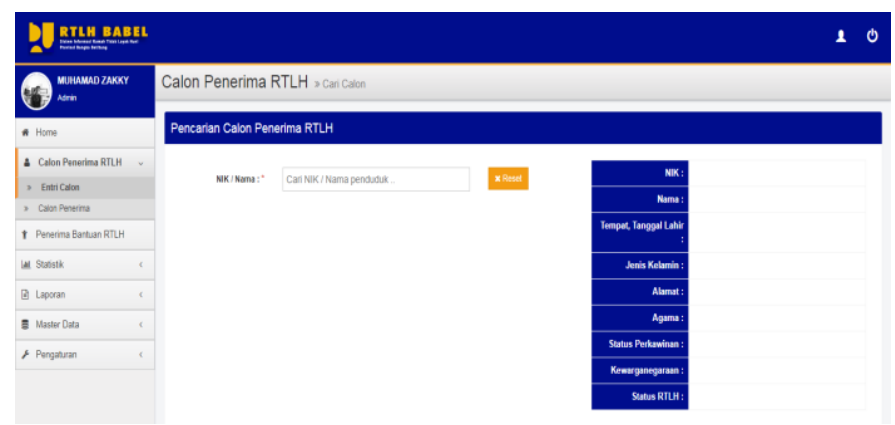

Gambar 6. User Interface Halaman Pencarian Calon Penerima

Pada gambar 6 diatas merupakan halaman pencarian calon penerima. Dalam pencarian calon penerima, admin cukup menginput NIK / Nama calon penerima.

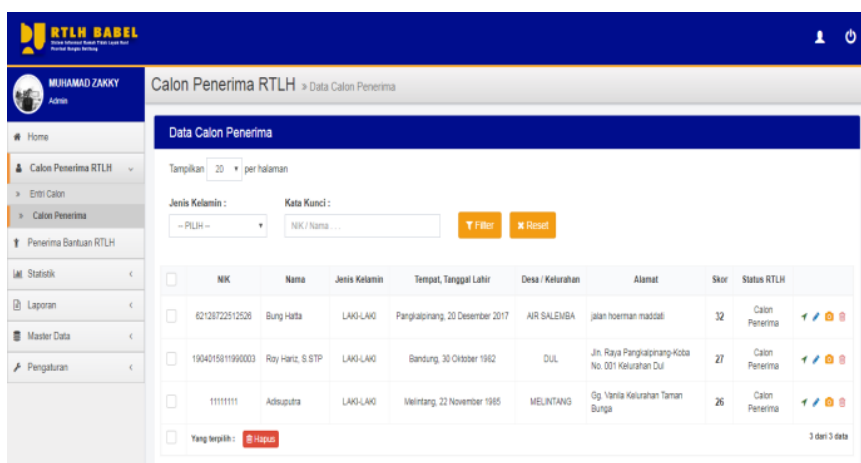

Gambar 7. User Interface Halaman Data Calon Penerima

Gambar 7 diatas merupakan halaman data calon penerima. Untuk melihat data calon penerima, Admin dapat melihat data dengan menginput NIK / Nama dan Jenis Kelamin.

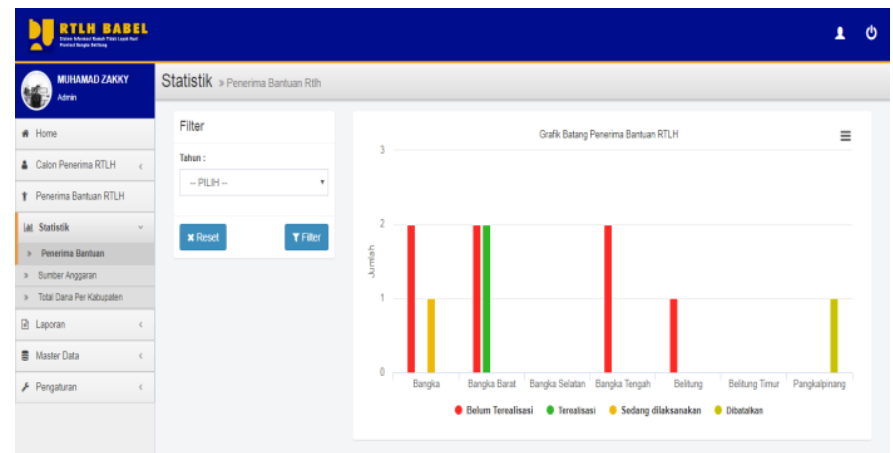

Gambar 8. User Interface Halaman Statistik Penerima Bantuan 
Gambar 8 diatas merupakan halaman statistik penerima bantuan. Admin dapat melihat data statistik penerima bantuan.

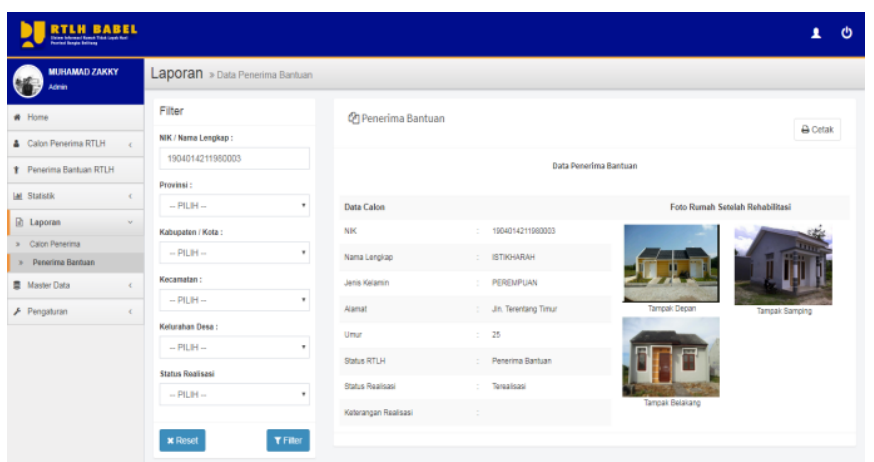

Gambar 9. User Interface Halaman Laporan Penerima Bantuan

\section{KESIMPULAN}

Berdasarkan penelitian yang telah dilakukan dapat disimpulkan beberapa hal sebagai berikut :

1. Telah berhasil membangun sistem pendukung keputusan penerima bantuan rumah tidak layak huni dengan kriteria kriteria penilaian pada dinas perumahan rakyat dan kawasan permukiman Provinsi kepulauan Bangka Belitung.

2. Sistem yang dibangun memberikan hasil yaitu skor nilai tertinggi berdasarkan perhitungan dari nilai kriteria kriteria pada Dinas Perumahan Rakyat dan Kawasan Permukiman Provinsi Kepulauan Bangka Belitung.
3. Sistem menghasilkan informasi alternatif keputusan untuk pemilihan penerima bantuan rumah tidak layak huni secara cepat.

4. Sistem dapat merepresentasikan tingkat kinerja instansi telah sampai dimana dalam bentuk grafik sehingga pimpinan dapat membuat kebijakan yang sesuai dan efektif dengan adanya informasi ini.

5. Manajemen data terkomputerisasi dengan rapi sehingga jika saat pimpinan daerah meminta data kepada instansi ini tidak membutuhkan waktu yang lama dan dapat dianggap efisien dan efektif.

6. Sistem yang dibangun dapat membantu pekerjaan tim penilai serta tim survei menjadi lebih sederhana dan efektif.

\section{DAFTAR PUSTAKA}

[1] Moh. Fayumi, 2017, Perancangan Aplikasi Pendataan Keluarga Miskin dengan Parameter Kondisi Rumah dan Penghasilan pada Kel. Alam, Jati uwung, Tugas Akhir, Sistem Informasi Manajemen, AMIK RAHARJA INFORMATIKA, Tangerang

[2] Rosa A.S M Shalahudin 2013. "Rekayaa Perangkat Lunak", Informatika, Bandung

[3] Adi Fajar Nugraha, 2014, Implementaso Progeam Rehabilitasi Sosial Rumah Tidak Layak Huni di Kota Serang, Serang : Universitas Sultan Ageng Tirtayasa

[4] Siti Mubaroqah, 2014, Implementasi Program Pembangunan Rumah Layak Huni di Desa Sangatta Utara Tahun 2014, Vol 2

[5] Romadhoni, E.N.A., Triyanna Widyaningtyas \& Utomo Pujianto., 2015. 'Implementasi Model Waterfall pada Pengembangan Sistem Informasi Alumni SMKN 1 Jenangan Ponorogo', Semarang, Seminar Nasional Sistem Informasi Indonesia 